\title{
ON THE ISSUE OF REPRODUCTIVE LOSSES PREVENTION IN UKRAINE
}

\author{
Alieva T.D.K. ${ }^{1,2}$, Shevchenko A. ${ }^{3}$ \\ ${ }^{1}$ Kharkiv National Medical University, Department of Medical Genetics \\ ${ }^{2}$ Ukrainian Institute of Clinical Genetics, Kharkiv, Ukraine \\ ${ }^{3}$ Kharkiv Regional Institute of Public Health Services, Kharkiv, Ukraine
}

https://doi.org/10.35339/ic.8.1.59-66

\begin{abstract}
The aim of the study was to determine the compliance of the existing medical care system in Ukraine for pregnant and married couples planning a pregnancy (its organizational and financial capabilities), the need to reduce the high level of reproductive losses. Materials and methods. Statistical methods and system analysis were used. The national programs of reproductive health, demographic data, data on morbidity (received from the national medical statistics for the period 2017-2018), reports of the national survey "Health Index. Ukraine" (2018), data on appeals for obstetric-gynecological, genetic care (in connection of reproductive losses, fertility) were analyzed. A comparison between the indicators of Ukraine and Kharkiv region, as well as with other countries, according to the cost of the survey, requested for medical care for the examination of genetic and infectious diseases associated with reproductive losses, was made. The organization of outpatient care for pregnant and married couples planning a pregnancy was analyzed in terms of availability and sources of payment for the services. Results. The number of Ukrainian women planning their first pregnancy aged 35 and over was increasing as well as the number of genetic pathologies. The indicators of infectious pathology remained high. Meanwhile, women visited less gynecologists and family doctors, which is due to the high cost of the part of medical care that the patients have to pay for themselves. Genetic screening programs for genetic diseases were poorly developed. The professional contacts of physician of various specialties required improvement. These facts negatively affected the level of reproductive losses, complicate their prevention. Conclusions. Our findings suggest that to reduce reproductive losses, it is necessary to create a national disease monitoring center, increase the availability of obstetric-gynecological and genetic care for the population, increase coverage of genetic screening programs, and give birth to children at the optimal age of 20-34.
\end{abstract}

Keywords: reproductive health, reproductive losses, fertility rates, screening genetic examinations.

\section{Introduction}

A key paradigm of the world health concept transformation is the transition from a responsive work model to a preventive, towards the so-called "4P medicine" model ("Predictive, Personalized, Preventive and Participatory approach to medicine"), where medicine proclaims, personalizes, prevents and requires patient involvement [1]. In such circumstances, the responsibility for maintaining

Corresponding Author:

Alexander Shevchenko, MD, master of medicine, economic \& pedagogy, Director of Kharkiv

Regional Institute of Public Health, Kharkiv, Ukraine.E-mail: al.shevchenko1976@gmail.com physical and mental health lies with the patient. In this case, health care becomes a service. But the emphasis is forced to shift in the preservation of the life and health of the pregnant and the fetus, due to the particular condition of the woman, who during pregnancy feels less controllable in her life and health, because she focuses on the preservation of the fetus at all levels of body functioning and the mind (conscious, subconscious, at the instinct level).

In a demographic crisis reality, the birth of every healthy baby is a priority for medical services at all levels and for medical science. The main concepts in the national programs "Health 2020: The Ukrainian Dimension" [2] and "Reproductive and Sexual Health of the Nation for the period 
2017-2021" have been outlined. According to these programs, the health status of the Ukrainian population is estimated to be unsatisfactory, including because of low birth rates combined with high mortality rates. The health care system is primarily aimed at treating patients rather than preventing diseases and detecting them early. This approach leads to an increase in primary disability and preventable mortality. To eliminate the negative impact of the social determinants of health, a responsible attitude of each person to personal health is needed, optimization of the care delivery system and intersectoral interaction both in medicine and between medicine, education system, public, etc. Specialists in prevention and early detection of diseases should also be trained.

From an anthropological point of view, reproduction of a population is necessary for its survival in conditions of relative isolation, and all factors that hinder it need to be studied for their elimination. Miscarriages, developmental disabilities (birth defects) incompatible with life, spontaneous abortions and other reproductive losses (RL) causes are actively studied in developed affluent countries of Western Europe, in the United States, but not enough in the poorer countries of the world. In addition, approaches to the study of these issues in many countries in South America, Africa and Asia are difficult to call complete [3, 4]. The strange situation is in Ukraine: according to the declarations, the approaches to the study are modern, in practice, even statistical data are not fully collected.

\section{Purpose, subjects and methods:}

\subsection{The purpose}

of the study was to determine the compliance of the existing medical care system in Ukraine for pregnant and married couples planning a pregnancy (its organizational and financial capabilities), the need to reduce the high level of reproductive losses.

\subsection{Subjects \& Methods}

In the context of the identified problems, the methods of statistical and systems analysis were applied. The female fertility rate of different ages, the ratio of the female population to the number of permanent population, the frequency of genital pathology and pregnancy complications, which affected the RL rates, the frequency of women seeking medical help from family doctors on reproductive health issues were examined. The indicators for the Kharkiv region were compared with the national ones, for which official statistics and data from the annual national survey "Health Index. Ukraine" [5] were used.
In 2018 [6], the "Health Index. Ukraine" survey was conducted by Kyiv International Institute of Sociology, the Social Indicators Foundation, the School of Health of the National University "Kyiv-Mohyla Academy" with the support of the International Renaissance Foundation and the World Bank. The survey is conducted annually to determine the actual level of satisfaction of Ukrainian citizens with medical care, covers each of the 24 regions of Ukraine (in Donetsk and Luhansk regions only in the territories controlled by Ukraine) and the city of Kyiv. More than 10,000 people took part in the survey. Survey indicators were either declared in the national "Health Reform Strategy 2015-2020" [7], or are considered important for evaluation attributes, or were available for the calculation of the Index. Assessment of 10 sub-indicators (e.g., visit to physicians in case of illness, satisfaction with medical care, cost of examination and treatment, knowledge of the symptoms of own disease) was conducted from 0 to 10 points per skin indicator (up to 100 points for each region). The results of the current year were compared with the results of the previous year.

Analysis of the state medical statistical reporting of treatment and prevention institutions of Kharkiv region according to the State Statistics Service of Ukraine, the Center for Medical Statistics of the Ministry of Health of Ukraine, the Main Department of Statistics in Kharkiv region (for the period 2008-2018), of the national annual statistical survey "Health Index. Ukraine" (for the 2018 compared to 2017) was completed. We studied the data on fertility, diagnosed malformations, visits to physicians of the relevant profile. Data sampling from forms No. 21 ("Report on medical care for pregnant, mothers and parturients" and No. 49 ("Report on the provision of medical and genetic care") are used.

The method of systems analysis [8] with modified by E.P. Golubkov was used. It involves setting a problem, research, analysis, preliminary judgment, confirmation, final judgment and implementation of the decision.

The preconception preparation, which was the focus of the study, applies to both married couples who are planning a pregnancy, but have a diagnosis of infertility, a high risk of hereditary diseases and history of RL, and pregnant with a high risk of miscarriage, birth defects, ectopic pregnancy and premature birth. Long-term observation of patients from the moment of planning the next pregnancy to the birth of a child is important both for the individual health of the 
offspring and for planning organizational measures to $R L$ reduction at the regional and national levels. This fact is taken into account in the proposed system of preconception training and verified by the method of system analysis.

Analysis of the state medical statistical reporting of treatment and prevention institutions of Kharkiv region according to the State Statistics Service of Ukraine, the Center for Medical Statistics of the Ministry of Health of Ukraine, the Main Department of Statistics in Kharkiv region (for the period 2008-2018), of the national annual statistical survey "Health Index. Ukraine" (2018 compared to 2017) was completed. We studied the data on fertility, diagnosed malformations, visits to physicians of the relevant profile. Data sampling from forms No. 21 ("Report on medical care for pregnant, mothers and parturients" and
No. 49 ("Report on the provision of medical and genetic care") were used.

\section{Results \& Discussion}

In Ukraine, Western Europe and the United States, pregnancy planning is gradually shifting towards the advanced age of parents. But the reasons are different: in affluent countries it is the pursuit of career growth that hinders the birth of children [9], in Ukraine - socio-economic difficulties that do not allow having not only another but at least one child. According to the literature in Western Europe countries, such cases are now about $5 \%$. Our calculation indicates a similar trend in Ukraine, at both regional and national level, which is shown in Table 1. Thus, since 2008, a gradual increase in the birth rate at the Ukraine and Kharkiv region in the age groups of 35-39 and 40-44 years was observed. In the

Table 1

Number of permanent population, pregnancies, occurring in women over 35 years* in Ukraine and Kharkiv region for the period 2008-2018, according to state statistics

\begin{tabular}{|c|c|c|c|c|c|c|c|c|c|c|}
\hline \multirow{3}{*}{ Year** } & \multicolumn{4}{|c|}{$\begin{array}{l}\text { Number of permanent population*** } \\
\text { on January } 1 \text { of the current year, thousands }\end{array}$} & \multicolumn{6}{|c|}{ Birth rates ${ }^{* * *}$ by mother's age, $\%$ o } \\
\hline & \multicolumn{2}{|c|}{ In Ukraine } & \multicolumn{2}{|c|}{ In Kharkov region } & \multicolumn{3}{|c|}{ In Ukraine } & \multicolumn{3}{|c|}{ In Kharkov region } \\
\hline & in all & women & in all & women & $\begin{array}{l}35-39 \\
\text { years }\end{array}$ & $\begin{array}{l}40-44 \\
\text { years }\end{array}$ & $\begin{array}{l}45-49 \\
\text { years }\end{array}$ & $\begin{array}{l}35-39 \\
\text { years }\end{array}$ & $\begin{array}{l}40-44 \\
\text { years }\end{array}$ & $\begin{array}{l}45-49 \\
\text { years }\end{array}$ \\
\hline 2008 & 46372.7 & 24894.6 & 2780.3 & 1504.9 & 19.7 & 3.3 & 0.2 & 19.0 & 2.9 & 0.1 \\
\hline 2009 & 46143.7 & 24778.4 & 2766.8 & 1497.3 & 21.5 & 3.8 & 0.2 & 20.3 & 3.6 & 0.2 \\
\hline 2010 & 45962.9 & 24675.5 & 2753.5 & 1489.6 & 22.3 & 4.2 & 0.2 & 20.1 & 4.3 & 0.2 \\
\hline 2012 & 45633.6 & 24476.6 & 2726.5 & 1473.4 & 26.4 & 5.0 & 0.3 & 25.6 & 4.7 & 0.4 \\
\hline 2013 & 45553.0 & 24410.0 & 2728.8 & 1469.9 & 27.2 & 5.2 & 0.3 & 24.8 & 5.0 & 0.5 \\
\hline 2014 & 45426.2 & 24327.6 & 2721.6 & 1464.3 & 27.6 & 5.5 & 0.4 & 28.0 & 5.4 & 0.7 \\
\hline 2015 & 42929.3 & 22971.9 & 2715.7 & 1459.3 & 27.3 & 5.6 & 0.4 & 25.6 & 5.4 & 0.3 \\
\hline 2016 & 42760.5 & 22873.0 & 2703.0 & 1451.3 & 27.3 & 5.8 & 0.5 & 25.3 & 5.1 & 0.4 \\
\hline 2017 & 42584.5 & 22770.3 & 2685.6 & 1440.9 & 26.7 & 5.9 & 0.7 & 24.4 & 5.4 & 0.5 \\
\hline
\end{tabular}

Notes:

* For our study, we selected a group of women who gave birth at first time after the age of 35 (socalled age-old primaparas) [14]. In these women, the incidence of genital pathology and complications in childbirth exceeds similar rates in women 20-30 years [15]. Thus, cases of uterine myomas account for $27.8 \%$, cervical ectropion $-17 \%$, chronic adnexitis $-6.7 \%$, infertility $-11.1 \%$, ureaplasmosis $-5.6 \%$, preeclampsia at 32 weeks of gestation and over $-50 \%$, anemia $-27,8 \%$, chronic placental insufficiency $16.7 \%$, pregnancy termination threats $-16.7 \%$, gestational diabetes $-5.5 \%$. With increasing of birth age, the frequency of the following states increased as well: premature birth, premature outflow of amniotic fluid (up to level $27.8 \%$ ), primary weakness of childbirth activity $(11.1 \%$ ), cervical ruptures $(11.1 \%)$, threatening perineal rupture $(5.5 \%)$, delays of litter parts $(5.5 \%)$. This age was also considered to be the safest for pregnancy and childbirth $[16,17]$.

** Since 2015, data have been submitted without taking into account the temporarily occupied territories of Donetsk, Luhansk region, Crimea and Sevastopol. Population calculations were made on the basis of available administrative data on state birth and death registration, as well as changes in residence registration.

*** Permanent Population - population that is permanently resident at the time of the census in a certain territory, including temporarily absent persons, if their absence in the place of permanent residence did not exceed 12 months.

**** Age-specific fertility rates (live births per 1,000 women of the appropriate age) - the ratio of live births per year in women of this age group to the average annual number of women at this age. In fact, this is the birth rate for the hypothetical generation, which does not depend on the age of the population [18]. 
age group of 45-49 years there is a trend of growth only at the national level noted, but this indicator fluctuated over the years in Kharkiv region.

Age-specific fertility rates in all countries of the world are traditionally calculated per 1,000 of the population corresponding age and in age groups of 5 years during the reproductive age (15-49 years) [19]. The state statistics organizations annually publish statistical data on fertility rates for all age groups of women, and the researchers select the age for which they conduct their research. The result of the arithmetic mean for the nearest age groups is not correct in cases where the researcher needs to show the age group, for example, women at 40-49 years age. In this case, it is necessary to process the primary data of the region or country, which includes the number of women of the appropriate age group and the number of children born by them. Similarly, total fertility rate of women aged 15-49 calculated as:

$$
F_{15-49}=\frac{N}{W_{15-49}} \times 1000,
$$

where $F_{15-49}$ - fertility rate of women aged 15 to 49 years;

$$
W_{15-49} \text { - the average number of women }
$$
aged 15 to 49 years;

$N$ - number of births.

At present, the availability of affordable, effective and safe contraceptives, as well as assisted reproductive technologies help to correct the reproductive cycle. The incidence of use of such technologies increases significantly $(p<0.001)$ with the age of pregnant at times after 40 years [20]: in the group younger than 40 years $3.3 \%$, in the group $40-44$ years $-7.9 \%$, older 45 years $-23,7 \%$. Obviously, extracorporeal fertilization can overcome the problem of infertility, but the hope of it and allows you to postpone pregnancy until later. While it is known that with increasing maternal age, the possibility of pregnancy fertilization and delivery decreases [21], increases the number of chromosomal abnormalities, pathological pregnancy $[22,23]$. The use of contraception allows delay in pregnancy beyond the parent's age, but also reduces the risk of sexually transmitted infections, which are responsible for a significant RL incidence.

Pregnancy planning for Ukrainian women under 35 should be facilitated by improved socioeconomic living conditions, as well as coordinated efforts by family doctors (general practitioners, GP), obstetrician and genetic services, prevention of unwanted pregnancies under 20 years by available contraceptive methods and family planning knowledge.

According to the annual national survey "Health Index. Ukraine-2018" [6], less than half $(46.7 \%)$ of women surveyed have visited a gynecologist for prophylactic purposes in the last 12 months (see Table 2). Among men, reproductive

Table 2

Number of women who visited

a gynecologist with a preventive purpose in 2017 and 2018 in different regions of Ukraine

(\% of the total number of respondents)

\begin{tabular}{|l|c|c|}
\hline \multirow{2}{*}{\multicolumn{1}{|c|}{ Region, city }} & \multicolumn{2}{c|}{ Year } \\
\cline { 2 - 3 } & 2017 & 2018 \\
\hline Vinnitsa region & 52.4 & 44.3 \\
\hline Volyn region & 15.0 & 18.7 \\
\hline Dnipropetrovsk region & 68.7 & 55.0 \\
\hline Donetsk region * & 38.6 & 43.7 \\
\hline Zhytomyr region & 57.0 & 63.1 \\
\hline Zakarpattya region & 47.6 & 41.4 \\
\hline Zaporizhzhya region & 31.0 & 42.5 \\
\hline Ivano-Frankivsk region & 56.0 & 54.6 \\
\hline Kyiv region & 55.8 & 50.3 \\
\hline Kirovograd region & 20.0 & 25.0 \\
\hline Luhansk region ${ }^{*}$ & 39.1 & 53.4 \\
\hline Lviv region & 45.6 & 47.7 \\
\hline Mykolaiv region & 67.4 & 60.9 \\
\hline Odessa region & 43.2 & 33.8 \\
\hline Poltava region & 54.4 & 62.9 \\
\hline Rivne region & 50.8 & 48.3 \\
\hline Sumy region & 48.9 & 44.9 \\
\hline Ternopil region & 45.9 & 46.8 \\
\hline Kharkiv region & 43.5 & 47.6 \\
\hline Kherson region & 56.4 & 59.3 \\
\hline Khmelnytsky region & 41.8 & 32.1 \\
\hline Cherkasy region & 68.1 & 56.8 \\
\hline Chernivtsi region & 69.8 & 56.3 \\
\hline Chernihiv region & 63.4 & 60.2 \\
\hline City of Kyiv & 32.0 & 29.7 \\
\hline All Ukraine & 47.5 & 46.7 \\
\hline
\end{tabular}

Note: * except the occupied part.

treatment rates are traditionally lower by about half (in $2017-24.0 \%$, in $2018-20.5 \%$ ). In addition, these figures decreased compared to 2017 for both women and men. There is also a strong statistical trend: as the age of women increases, the percentage of those who undergo screening is declining. In 2018, it was $66.4 \%$ in women aged 18 to 29 years, in 30-44 years $58.3 \%$, 45-59 years $-48.2 \%$, over 60 years $24.9 \%$. Another constant observation: more women with higher education are turning to medics for prevention. 
The number of referrals to GP is increasing: in 2016 this figure was $25.5 \%$, in $2017-30.1 \%$, in $2018-34.8 \%$. This was facilitated by the fact that in the last two years, declarations have been signed between the population and GP [24]. Interviewed Ukrainians consider the main barriers to receiving medical care to be large queues, lack of confidence in the qualifications of doctors, poor treatment of patients, high cost of treatment, lack of transportation, lack of understanding of which doctor to consult, others. The cost of treatment is seen as a barrier to an increasing proportion of patients (24.6\% in 2016, 22.9\% in 2017 and $17.0 \%$ in 2018). In 2018, residents of Zakarpattya region $(39.6 \%)$ and Kyiv region $(31.1 \%)$ were most concerned with treatment, while residents of Ternopil region ( $0 \%$ ) and Volyn region $(2.1 \%)$ were the least concerned. Among the residents of Kharkiv region, $21.5 \%$ of respondents indicated this factor in the survey. Large queues should be positively impacted by electronic enrollment systems, at high cost by the state system of medical guarantees and the introduction of insurance medicine.

Outpatient care for all issues was addressed by $36 \%$ of Ukrainians in $2016,37 \%$ in 2017 , and only $33 \%$ in 2018 [25]. The establishment of a primary care system, in which a GP now plays a leading role, will allow the patients receiving medical referrals to narrow specialists to obtain reimbursement of the costs of secondary and tertiary care professionals at the expense of state medical guarantees. Only two out of five interviewed patients who received help from a narrow specialist had a referral (41.7\%), but this is $1.5-2$ times more than in previous years.

The number of referrals to GPs in 2018 was in fact equal to the number of referrals to specialists of all profiles (35\% and $34 \%$, respectively). Other referrals were to district internists (29\%) and general practitioners $(2 \%)$. Among the residents of Kharkiv and Kirovohrad regions, the numbers of referrals to GPs were $13.6 \%$ and $11.0 \%$, respectively), among the residents of Volyn region - the highest $(68.5 \%)$. The largest number of appeals to specialists was among the residents of Ivano-Frankivsk region $(51.4 \%)$. Among those who referred to a GP or a district internist/pediatrician, they had $20.9 \%$ of patients in $2016,28.5 \%$ in 2017 and $41.7 \%$ in 2018. In 2018, this was the highest in Dnipropetrovsk region $(60.2 \%)$, the lowest in Vinnytsia region (11.5\%). Among the reasons for seeking outpatient care to highlight our topic are the most important infectious diseases, which is one of the main causes of miscarriage and RL. Such cases, together with complaints about pregnancy in 2018 in different regions of Ukraine are shown in table 3. Among other investigated reasons of complaints were diseases of the circulatory system (25.2\%),

Table 3

Specific reasons for the last outpatient visit to physicians in 2018 in Ukraine related to fertility and reproductive losses (regional distribution, \%)

\begin{tabular}{|l|c|c|}
\hline \multirow{2}{*}{\multicolumn{1}{|c|}{ Region, city }} & \multicolumn{2}{c|}{ Reason for appeal } \\
\cline { 2 - 3 } & Pregnancy & $\begin{array}{c}\text { Infectious } \\
\text { diseases }\end{array}$ \\
\hline Vinnitsa region & 0.0 & 1.5 \\
\hline Volyn region & 8.3 & 1.8 \\
\hline Dnipropetrovsk region & 0.5 & 0.4 \\
\hline Donetsk region * & 1.2 & 1.3 \\
\hline Zhytomyr region & 5.6 & 3.4 \\
\hline Zakarpattya region & 0.0 & 1.1 \\
\hline Zaporizhzhya region & 0.9 & 1.0 \\
\hline Ivano-Frankivsk region & 0.7 & 1.6 \\
\hline Kyiv region & 1.2 & 0.0 \\
\hline Kirovograd region & 1.1 & 0.4 \\
\hline Luhansk region ${ }^{*}$ & 0.0 & 1.2 \\
\hline Lviv region & 0.0 & 0.0 \\
\hline Mykolaiv region & 0.0 & 0.0 \\
\hline Odessa region & 0.9 & 2.0 \\
\hline Poltava region & 4.1 & 0.4 \\
\hline Rivne region & 3.2 & 0.5 \\
\hline Sumy region & 0.7 & 0.0 \\
\hline Ternopil region & 0.0 & 0.0 \\
\hline Kharkiv region & 0.0 & 2.0 \\
\hline Kherson region & 0.7 & 0.0 \\
\hline Khmelnytsky region & 0.0 & 3.1 \\
\hline Cherkasy region & 1.0 & 0.6 \\
\hline Chernivtsi region & 0.0 & 1.7 \\
\hline Chernihiv region & 0.0 & 0.0 \\
\hline City of Kyiv & 1.2 & 0.9 \\
\hline All Ukraine & & 0.0 \\
\hline
\end{tabular}

Note: * except the occupied part.

respiratory organs $(30.7 \%)$, locomotive system and connective tissues (5.9\%), trauma, poisoning and other external influences $(6.4 \%)$, diseases of the genitourinary system $(4.7 \%)$, neoplasms $(1.5 \%)$, diseases of the endocrine system $(3.7 \%)$, nervous system $(1.7 \%)$, eye and its accessory organs $(1.2 \%)$, skin and subcutaneous tissue $(1.2 \%)$, ears $(0.9 \%)$, mental and behavioral disorders $(0,2 \%)$, diseases of blood and hematopoietic organs $(0,2 \%)$, digestive organs $(4,5 \%)$.

Interaction of GPs with obstetric and genetic health services should give Ukrainians the opportunity to receive timely information about the risks of pathological pregnancy, miscarriage, fetal malformations, the development of rare (orphan) diseases (that are progressive chronic diseases, with frequency in a population 1:2000 or less, with risk of death or disability [25]). The 
presence of such diseases is closely linked to the overall RL rate. Therefore, the state must allocate the necessary resources for their timely diagnosis. The rare diseases should be offset by well-planned genetic screening studies [26] that cover all at-risk groups (including infertility, miscarriage and birth defects in obstetric anamnesis), and not high-cost [27].

According to the same principles, treatment and prevention measures should be planned. Such a goal is easily achievable, given the absence of specific pathogenetic pharmaceuticals for the treatment of genetic diseases. Conversely, it is known [28] that the use of natural therapeutic factors, vitamins and rehabilitation measures contribute to the improvement of cytogenetic status, burdened with anthropogenic influences. Therefore, the scheme of preconception medical care for pregnancy should include individual cofactor therapy, taking into account the results of biochemical and molecular examination of women [29], taking probiotics, which according to the studies of Kirihara et al. [30] significantly reduces the risk of prematurity.

In addition to low-cost examinations (for example, ultrasound, biochemical tests for the exchange of amino acids of the folate cycle), the practice of genetic genetics also uses complex and costly methods of chromosomal and gene analysis. The cost factor has repeatedly prompted researchers from different countries to conduct an economic analysis to determine the feasibility of mass surveys. Thus, Van Leeuwen et al. [31] determined the cost of preventing the birth of one child in the range of 226,000 to 6,556,000 thousand euros, with the difference depending on the pathology detected, the number of previous miscarriages and other obstetric history, examinations (for example, whether a chromosomal history was combined with an amniotic history). The economic feasibility of prophylaxis during recurrent pregnancies ranged from 2,000 to 223,000 euros for each case of preventing the birth of a disabled child.

The use of an extended model of care assistance in cases of suspicion instead of the standard one was also economically justified in the case of early pregnancy loss [32]. The experience of many countries (e.g., India [33] and Zambia [34]) points to the economic losses in the health care system as a result of the abortion ban, which also increases the risk of dangerous abortion and maternal mortality. Thus, the Ministry of Health of Zambia could save $\$ 400,000$ a year in treating the effects of dangerous abortions. Upgrading aid schemes to women in need of termination of pregnancy on medical grounds reduces the direct economic losses of national health care systems and families in which children with genetic pathologies are born.

For the planning of reproductive loss prevention measures, it is advisable to use models of predicting the detection of genetically induced diseases [35], which are based on statistical observations of population morbidity, and take into account the potential of national and regional health systems, as well as the dynamics of changes during reform. At the present stage, the Ministry of Health of Ukraine is developing processes of power distribution between several new structures, which are responsible for certain areas of medical, preventive work and medical education. At the time of making proposals for improving genetic monitoring programs, as well as establishing a Ukrainian National Center for Disease Prevention and Control at the Ministry of Health of Ukraine, which should operate under the scheme of the US Center of the same name (CDC in Atlanta), and carry out those studies for which budget funds will be available, on the list in order of weight for the community and the medical community. But unlike the US Center, we suggest that genetic diseases will receive high priority.

\section{Conclusions}

1. When planning preventive measures to reduce reproductive losses, statistics from previous years, the possibilities of regional and national health care systems, models and ways of reforming them, public perceptions of these initiatives, barriers to receiving medical assistance should be considered.

2. For the full compilation in the regions of medical statistics data used in reproductive loss reduction planning, centralized analysis and public discussion in professional circles requires a national disease control and prevention center in Ukraine, where genetic monitoring programs should be prioritized along with infectious, oncological and cardiovascular diseases, despite the higher prevalence of the latter.

3. Ukraine needs a program to promote pregnancy planning at the optimum age of 20 to 35 years. All key medical specialties - GPs, gynecologists, internists and geneticists - should be involved in its implementation. Preconceptual health care for pregnancy should include individual cofactor therapy, taking into account the results of instrumental, biochemical and molecular genetic examination of a woman.

Conflict of interest

The authors declare no conflicts of interest. 


\section{References}

1. Alonso, S. G., de la Torre, D. I., Zapirain, B.G. (2019). Predictive, Personalized, Preventive and Participatory (4P) Medicine Applied to Telemedicine and eHealth in the Literature. J Med Syst, 43(5), 140. DOI: $10.1007 / \mathrm{s} 10916-019-1279-4$.

2. On approval of the Concept of the National Program "Health 2020: Ukrainian Dimension": Cabinet of Ministers of Ukraine Decree No. 1164-p, October 31, 2011. Government portal: Unified web portal of the executive authorities of Ukraine. Retrieved from: https://www.kmu.gov.ua/npas/244717787 [In Ukrainian].

3. Bennett, L. R., de Kok, B. (2018). Reproductive Desires and Disappointments. Med Anthropol, 37(2), 91-100. PMID: 29257897. DOI: 10.1080/01459740.2017.1416609.

4. Bennett, L. R. (2018). Infertility, Adoption, and Family Formation in Indonesia. Med Anthropol, 37(2), 101-116. PMID: 29182369. DOI: 10.1080/01459740.2017.1407931.

5. Health Index. Ukraine. Retrieved from: http://health-index.com.ua [In Ukrainian].

6. Health Index. Ukraine-2018: Results of a nationwide survey. Compiled by Stepurko T.G. [et al.]. Kyiv, 2018. 172 p. Retrieved from: http://health-index.com.ua/zvit_index_2018_eng.pdf [In Ukrainian].

7. National strategy for reforming the health care system in Ukraine for the period 2015-2020. Ministry of Health of Ukraine. International Renaissance Foundation. Kyiv, 2015. 41 p. [Electronic resource]. Retrieved from: https://www.moz.gov.ua/ua/portal/Pro_20150518_2.html

8. Volkova, V.N., Denisov, A.A. (2012) Systems theory and systems analysis: a textbook for bachelors. M.: Yurayt Publishing House. 679 p. ISBN 978-5-9916-1443-6 [In Russian].

9. Artini, P. G., Obino, M. E., Vergine, F., et al. (2018). Assisted reproductive technique in women of advanced fertility age. Minerva Ginecol, 70(6), 738-749. PMID: 29856189. DOI: 10.23736/S00264784.18.04247-8.

10. Demographic passport of the territory. State Statistics Service of Ukraine. Retrieved from: http:/ /database.ukrcensus.gov.ua [In Ukrainian].

11. Permanent population of Ukraine 1990-2017. State Statistics Service of Ukraine. Retrieved from: http://www.ukrstat.gov.ua/operativ/operativ2007/ds/nas_rik/nas_u/nas_rik_u.xlsx [In Ukrainian].

12. Population of Kharkiv region 1990-2018. General Department of Statistics in Kharkiv region. URL: http://kh.ukrstat.gov.ua/naselennia-1995-2012 [In Ukrainian].

13. Timonina, M.B. (2019). Fertility, mortality, and average life expectancy tables for 2018. Statistical Collection. Kyiv: State Statistics Service of Ukraine, 2019. 66 p. Retrieved from: http://ukrstat.gov.ua/ druk/publicat/kat_u/2019/zb/08/zb_tabl_nar_2018.pdf [In Ukrainian].

14. Demenina, N. K. Podolsky, V. V., Sorokin, A.V., et al. (2014). Features of pregnancy and childbirth in older women (literature review). Proceedings of the Association of Obstetricians-Gynecologists of Ukraine, 33/34(1/2), 107-110 [Citing the recommendations of the International Federation of Gynecology and Obstetrics (FIGO)] [In Russian].

15. Mirsaidova M.U. (2004). Features of the gestational process, childbirth, perinatal consequences, postpartum period and lactation in women of late reproductive age: Abstract of $\mathrm{PhD}$ diss. med. spec. "Obstetrics and Gynecology". Dushanbe. 19 p. [In Russian].

16. Hincz, P., Wojciechowska, E., Podciechowski, L., Kubiak, A., et al. (2006). Late maternity: the pregnancy and delivery in women after 35 years of age. Menopause Review / Przegl?d Menopauzalny, 5(2), 80-84. Retrieved from: https://www.termedia.pl/Late-maternity-the-pregnancy-and-delivery-inwomen-after-35-years-of-age,4,5940,0,1.html

17. Ustun, Y., Engin-Ustun, Y., Meydanil, M., et al. (2006). Maternal and neonatal outcomes in pregnancies at 35 and older age group. J Turkish German Gynecol Assoc, 6, 46-48.

18. Morbidity of the population of Ukraine 1990-2017. State Statistics Service of Ukraine. Retrieved from: http:/www.ukrstat.gov.ua/operativ/operativ2007/oz_rik/oz_u/zahvor_06_u.html [In Ukrainian].

19. Total Fertility. UN Population Division. Retrieved from: https://www.un.org/en/development/desa/ population/publications/dataset/fertility/total-fertility.asp

20. Marozio, L. Picardo, E., Filippini, C. et al. (2019). Maternal age over 40 years and pregnancy outcome: a hospital-based survey. J Matern Fetal Neonatal Med, 32(10), 1602-1608. PMID: 29216770. DOI: $10.1080 / 14767058.2017 .1410793$.

21. Sauer, M. V. (2015). Reproduction at an advanced maternal age and maternal health. Fertil Steril, 103(5), 1136-1143. PMID: 25934599. DOI: 10.1016/j.fertnstert.2015.03.004. 
22. Frederiksen, L. E., Ernst A., Brix N., et al. (2018) Risk of Adverse Pregnancy Outcomes at Advanced Maternal Age. Obstet Gynecol, 131(3), 457-463. PMID: 29420406. DOI: 10.1097/ AOG.0000000000002504.

23. Nilsson, S. F. Andersen, P. K., Strandberg-Larsen, K., et al. (2014). Risk factors for miscarriage from a prevention perspective: a nationwide follow-up study. BJOG, 121(11), 1375-1384. PMID: 24548778. DOI: 10.1111/1471-0528.12694.

24. About Approval of the Procedure for Selection of Primary Care Medical Doctor and Forms of Declaration on Primary Care Doctor Selection: Ministry of Health Care Order No. 503, March 19, 2018 (in force). Legislation of Ukraine, official site of the Verkhovna Rada. Retrieved from: https:// zakon.rada.gov.ua/laws/show/z0347-18 [In Ukrainian].

25. Fundamentals of the Legislation of Ukraine on Health Care: Law of Ukraine No. 2801-XII, November 19, 1992, amended 1992-2019 (in force) (1993). Bulletin of the Verkhovna Rada of Ukraine, (4), Art. 19. [Cit.: Legislation of Ukraine, official site of the Verkhovna Rada] Retrieved from: https://zakon.rada.gov.ua/ laws/show/2801-12 [In Ukrainian].

26. Jauniaux, E., Bhide, A. (2017). Prenatal ultrasound diagnosis and outcome of placenta previa accreta after cesarean delivery: a systematic review and meta-analysis. Am J Obstet Gynecol, 217(1), 27-36. PMID: 28268196. DOI: 10.1016/j.ajog.2017.02.050.

27. Alieva, T.D.K. (2019). Medical and social services for prevention of congenital birth defects, in the aspect of the amine acid alteration in blood. Bull KhRIPHS, 87(1), 53-66. DOI: 10.5281/zenodo.3601660 [In Ukrainian].

28. Klimkin I.I. (2003). Cytogenetic assessment of mutagenic danger of urbanized territories of Ukraine: Abstract of PhD diss. biol. sc., spec. 03.00.15. O.M. Marzeyev Institute of Hygiene and Med. Ecol. AMS of Ukraine, Kiyiv. 20 p. [In Ukrainian].

29. Alieva, T.D.K. (2019). Principles of risk prevention of early reproductive losses in the context of oligonucleotide polymorphism of folate cycle genes. Bull KhRIPHS, 89(3), 4-23. DOI: 10.5281/ zenodo.3582796 [In Ukrainian].

30. Kirihara, N., Kamitomo, M., Tabira, T., et al. (2018). Effect of probiotics on perinatal outcome in patients at high risk of preterm birth. J Obstet Gynaecol Res, 44(2), 241-247. PMID: 28994162. DOI: 10.1111/jog. 13497.

31. Van Leeuwen, M., Vansenne, F., Korevaar, J. C., et al. (2013). Economic analysis of chromosome testing in couples with recurrent miscarriage to prevent handicapped offspring. Hum Reprod, 28(7), 1737-1742. PMID: 23613277. DOI: 10.1093/humrep/det067.

32. Dalton, V., Liang, K. A., Hutton, D. W., et al. (2015). Beyond usual care: the economic consequences of expanding treatment options in early pregnancy loss. Am J Obstet Gynecol, 212(2), 177, e1-6. PMID: 25174796 DOI: 10.1016/j.ajog.2014.08.031

33. Banerjee S. Kumar K. R., Warvadekar J. et al. (2017). An exploration of the socio-economic profile of women and costs of receiving abortion services at public health facilities of Madhya Pradesh, India. BMC Health Serv Res, 17(1), art. No. 223. DOI: 10.1186/s12913-017-2159-6.

34. Parmar, D., Leone, T., Coast, E., et al. (2017). Cost of abortions in Zambia: A comparison of safe abortion and post abortion care. Glob Public Health, 12(2), 236-249. PMID: 26708223. DOI: 10.1080/ 17441692.2015 .1123747$.

35. Galagan, V. A. (2004). Medical-genetic counseling in the system of genetic monitoring of the population: Abstract of diss. Doc. Med. Sc., spec. 03.00.15. O.M. Marzeyev Institute of hygiene and med. ecol. AMS of Ukraine, Kiyiv. 42 p. [In Ukrainian].

Received: 04-Dec-2020 Accepted: 16-Mar-2021 